\title{
The Potential Value of Evaluation as Budgeting Tool for South African Municipalities
}

MOFOLO, Malefetsane A.

\section{Abstract}

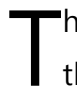

he paradox around performance in

the South African municipalities is undoubtedly exposed by the released reports of the Auditor-General for 2012/13 and Statistics South Africa's Non-Financial Census of Municipalities, 2013. On the analyses of these reports, it became clear that municipalities could achieve more if stringent measures could be put in place and implemented to ensure that resources are used efficiently and effectively. To that effect, this article argues that monitoring and evaluation (M\&E) policy framework should be fully implemented in South African municipalities.

This argument emanates from the fact that exorbitant amounts are incurred on fruitless and wasteful expenditure in municipalities. This article then presents a compelling case through which maximisation of expenditure prioritisation in municipalities is warranted. To investigate the concept of expenditure prioritisation, as a principle that municipalities should espouse, the study embarks on literature review as a method deemed suitable to explore the value of evaluation as budgeting tool for South African municipalities.

The findings to this investigation, recommended that on-going or process evaluation should be more useful to inform budget decision makers in the provincial and national governments about the required capacity interventions, which could assist to deal with financial weaknesses in municipalities.

Keywords: Budgeting, Auditor-General, Non-financial Census, Monitoring and Evaluation (M\&E), Expenditure Prioritisation. 


\section{Introduction}

The paradox around performance in South African municipalities is undoubtedly exposed by recently released reports of the Auditor-General for 2012/13 and Statistics South Africa's Non-Financial Census of Municipalities 2013 (2014). On one hand, the report of the Auditor-General shows that unauthorised, irregular and wasteful municipal expenditure is persistently exorbitant. It is known that an amount of R9bn was spent on unauthorised expenditure, R11bn on irregular expenditure, and an extensive amount of R815m was incurred on fruitless and wasteful expenditure (Setumo, 2014).

On the other hand, the Statistics South Africa's (2014) report on the Non-Financial Census of Municipalities 2013, indicates that municipalities are making strides towards service delivery in South Africa. The census reveals that there has been an increase of the number of consumer units receiving basic services from municipalities since 2012 to 2013. According to this census, the largest increase in the rendering of services has been recorded in the provision of sewage and sanitation at 6,2 percent, followed by solid waste management at 5, 1 percent, water at 3, 3 percent, and electricity at 2, 3 percent (Statistics South Africa, 2014). However, it is also reported that the number of households that are using the bucket system have increased from 73413 in 2009 to 99102 in 2013 (Mbanjwa, 2014).

When one analyses these reports, it becomes clear that municipalities could achieve more if stringent measures could be introduced and implemented to ensure that resources are used efficiently and effectively. Efficiency refers to the achievement of policy, programme or project objectives with the least amount of money. While, effectiveness means the achievement of objectives (Van der Waldt \& Du Toit, 1997:19 citing Koontz \& Weihrich, 1985).

The fact that some noticeable progress is still reported despite the Auditor-General's report, it is an indication that the people could benefit more if resources are correctly directed towards basic service needs in South Africa. It is actually discouraging to incur such an amount on fruitless and wasteful expenditure, when certain service delivery needs do not take place.

According to Treasury (2000:40), fruitless and wasteful expenditure is expenditure made in vain, which could have been avoided had reasonable care been taken. This then presents a compelling case through which maximisation of expenditure prioritisation in municipalities must be sought. Expenditure prioritisation refers to government's 
allocation of resources to the programmes or projects that deliver the greatest benefits to the community (Robinson, 2014:8).

As a point of departure, this article argues that a Monitoring and Evaluation (M\&E) policy framework should be fully implemented in South African municipalities. The time has arrived that municipalities should move away from only using monitoring for the purposes of reporting, planning, and budgeting. But also, evaluation should be given space to generate information that could be useful to decision-makers. It is clear that the purposes of evaluation and monitoring differ, even though they supplement each other (Cloete \& De Coning, 2011:197; ljeoma, 2010:349-350).

\section{Definition of Monitoring and Evaluation}

While monitoring is defined as: collecting, analysing and reporting data on inputs, activities, outputs, outcomes and impacts as well as external factors in a way that supports effective management (Presidency, 2007:1), evaluation is defined as the systematic collection and objective analysis of evidence on public policies, programmes, projects, functions and organisations to assess issues such as relevance, performance (effectiveness and efficiency), value for money, impact and sustainability, and to recommend ways forward (Presidency, 2011:vii).

Evaluation in its Latin origin, valére means to work out the value of something (Cloete \& De Coning, 2011:196). This then indicates that, if the value of programmes, projects, and other municipal activities could be systematically deliberated upon, and subsequently the information be used to form the basis of budgeting; municipalities could stand a good chance of avoiding fruitless and wasteful expenditure. The understanding should be that, the value of municipal programmes, projects and other activities should determine the levels of funding or otherwise, the expenditure cuts. This simply implies that expenditure prioritisation should be emphasised (Robinson, 2014:6).

The concept 'expenditure prioritisation', a principle that municipalities should espouse should receive attention, as well as indicating that in this article, the concepts 'local government and municipality' are used interchangeably, expressing the same idea. Similarly, the word 'resources' is used only to denote financial resources in this article. 


\section{The Fiscal Challenges facing South Africa}

At this stage, it is a known fact that South Africa is still facing the challenges of a recession. Since the 2008 global financial crisis, tax revenue as a percentage of Gross Domestic Product (GDP) has been declining. According to Cloete (1995:35), GDP can be seen as the total value of goods and services of a country in a year. The impact of this decline of tax revenue as a percentage of GDP, has had a negative impact on government budget size and financial resources that should have been spent on twelve priority sectors, namely, Basic Education; Health; Safety and Security; Employment; Skills; Infrastructure; Rural Development; Human Settlements; Local Government; Environment; International Relations; and Public Services (Lomahoza, Brockerhoff, \& Frye, 2013:6).

However, in February 2014, in his State of the Nation Address, President Jacob Zuma had to say:

We are still going through a difficult period. Developments in the United States economy have led to a rapid depreciation in the emerging market currencies, including rand. During the course of 2013, the rand depreciated by 17.6 per cent against the US dollar. The weaker exchange rate poses a significant risk to inflation and will also make our infrastructure programme more expensive. [...]. While we have these difficulties, we know that we can cope with this period of turbulence. We have done so before in the past five years. We will, in fact, emerge stronger if we do the right things.

From this, it can be concluded that evaluation should be emphasised to ensure that limited resources are allocated to the most pressing problems and the most effective and efficient programmes and projects in order to cope with this depressing period (Cloete \& De Coning, 2011:197).

\section{Legal and Policy Mandate of Local Government}

Local government is the sphere of government in South Africa that is closely placed to the people in order to carry out the responsibilities of service delivery to ensure growth and development to the community (White Paper on Local Government, 1998: ix). To this end, section 152(1) of the Constitution of the Republic of South Africa, 1996 mandates local government to:

- provide democratic and accountable government for local communities; 
- $\quad$ ensure the provision of services to communities in a sustainable manner;

- promote social and economic development;

- promote a safe and healthy environment; and

- encourage the involvement of communities and community organisations in the matters of local government.

Section 152(2) of the Constitution of the Republic of South Africa, 1996 further stresses that a municipality should strive within its financial and administrative capacity to achieve these mandates. To achieve the above-mentioned mandates, the White Paper on Local Government, 1998 establishes a vision of a developmental local government, which should be committed to work with local communities to find sustainable ways to meet their needs, and also increase the quality of their lives (White Paper on Local Government, 1998: x). To this end, it is required of local government in exercising its powers and functions, to maximise impact on the socio-economic development of communities, particularly meeting the basic needs of the poor (White Paper on Local Government. 1998:18).

The White Paper on Local Government (1998:19) mandates local government to provide a vision and leadership in integrating and coordinating contribution of different agencies, such as national and provincial departments, parastatals, trade unions, community groups and private sector institutions in the development of the local areas in South Africa. The principles of co-operative government and intergovernmental relations provide that all interactions of the three spheres, namely, national, provincial, and local governments, must take place in a coordinated and cooperative way (Constitution, 1996)

Therefore, in order to meet this mandate, the Municipal Systems Act (Act No.32 of 2000) prescribes that a municipality must undertake developmentally-oriented planning to ensure that it strives to achieve the objects of local government set out in section 152 of the Constitution of the Republic of South Africa, 1996; and that together with other institutions of state contribute to the progressive realisation of the fundamental rights. Sections 24 and 27 of the Bill of Rights in the Constitution of the Republic of South Africa, 1996, grants the rights to the South African citizens to have access to sufficient water, an environment not harmful to health and well-being, and protected environment from degradation. 
From the analysis of these statutory legislative frameworks, it becomes quite clear that local government resources should be channelled towards meeting the fundamental rights or socio-economic rights of the people in South Africa. In order to achieve these rights, municipalities are required to prioritise, and the criteria that should be used to determine priorities should be investigated into.

\section{Priority Indicators}

When decision makers contemplate to introduce new programmes/projects or extend the existing ones as part of planning, it is critical that the priorities should be firstly determined within the context of budgetary constraints (Erasmus \& Visser, 1997:133). In other words, decision makers should be able to make rational decisions in allocating limited resources by linking the budget of municipal programmes, projects, and other activities to evaluation (Schwella, Burger, Fox, \& Müller, 1996:148).

To this, there are certain criteria that decision makers could use to determine priorities when allocating resources in local government. According to Erasmus \& Visser (1997:133), National Treasury (2011), and Seemela (2009:54-55), the following priority indicators are applicable for this purpose:

\section{- Absolute priority}

This priority refers to the fact that the omission or delay of certain programmes or projects could be catastrophic. For example, life-threatening situations, services required by the Constitution as shown earlier in this article, such as public health, issues of water, sewerage, and electricity should be highly prioritised.

\section{- Essential expansions or new programmes}

Essential expansions or new programmes refer to programmes or projects that cannot be neglected or delayed without seriously prejudicing public interest. For example, general health, civil protection, new services relating to provision of water, refuse, sewerage, and the provision of electricity should be considered as essential and deserving to be prioritised.

\section{- Desirable expansions or new programmes}

Desirable expansions or new programmes relate to programmes or projects that should enjoy preference due to the extraordinary or specific economic, social or 
political advantages that they could have for the community. In other words, these are programmes or projects that could benefit the community by creating jobs; and promoting health and skill development.

- Useful expansions or new programmes

Useful expansions or new programmes are programmes or projects that although expendable, are important and have to be delivered by government in the public interest.

\section{- Expendable extensions or new programmes}

Expendable extensions or new programmes relate to programmes that government may drop or postpone without doing any material effect to the community. For example, projects that are meant for comfort or pleasant life style should be regarded as low priorities.

These priority indicators give a clear indication that fundamental rights or socioeconomic rights of the citizens of South Africa should come first, and therefore, they should be seriously considered when municipalities spend money. This simply means that, the constitutional rights would be violated if a municipality fails to budget adequately to meet its obligation of delivering basic services in favour of other municipal activities or provincial activities (DBSA, 2009:4).

Furthermore, the priority indicators also provide a scale or hierarchy which indicates level of preference for public spending. This shows that expenditure reductions or cuts should be effected following priority indicators as shown above. Expressing it differently, it shows that expenditure prioritisation should always identify cuts as opposed to introducing other areas for new spending, which then necessitates the investigation of the legality of M\&E in South Africa.

The four principal sources of M\&E are contained in the Constitution, 1996, Government-wide Monitoring and Evaluation (GWM\&E), Framework for Managing Programme Performance Information (FMPPI), and National Evaluation Policy Framework, which are discussed below.

\section{Legal basis of Monitoring and Evaluation in South Africa}

Firstly, the statutory framework that regulates the availability of M\&E in South Africa is the Constitution, 1996. Chapter 10 of the Constitution stipulates the basic values and 
principles that govern South African public administration. To this effect, section 95 of the Constitution, inter alia, prescribes that:

- Efficient, economic and effective use of resources must be promoted;

- Public administration must be development-oriented;

- Public administration must be accountable;

- Transparency must be fostered by providing the public with timely, accessible and accurate information (Presidency, 2011:1).

Subsequently, the Municipal Finance Management Act (Act No.56 of 2003) (MFMA) gives effect to the constitutional principle that considers local government as a distinctive and independent sphere that has the power to determine its own budget and policies. Furthermore, MFMA, together with other Acts, such as the Public Finance Management Act (Act No. 1 of 1999) (PFMA); the Public Service Act (Act No. 103 of 1994 as amended by Act 30 of 2007) provide the legal basis for the efficient and effective management of public policies and programmes in South African public service (Presidency, 2011:1).

Similarly, the above-mentioned Acts, also provide a legal basis for the implementation of various types of evaluation (Presidency, 2011:1). Therefore, looking at the policy that regulates M\&E, a brief historical development of these policy frameworks is provided.

\section{Historical Development of Monitoring and Evaluation frameworks in South Africa}

In the year 2005, the government of South Africa had realised the need to enhance its policy on M\&E so that decision making and resource allocation can be improved. As a result, the Policy Framework for the Government-wide Monitoring and Evaluation System was approved by Cabinet to provide the overall framework for M\&E in South Africa (DNA Economics, 2011:3).

In the year 2007, the Policy Framework for the Government-wide Monitoring and Evaluation System (GWM\&E) was launched. This Policy Framework is applicable to all government bodies in the national, provincial and local spheres of governments; and it provides three data terrains which underpin GWM\&E. Each of these data terrains is a policy subject that clearly stipulates what is expected of them (data terrains) in order to be fully functional. To this end, the National Treasury has introduced a Framework for 
Managing Programme Performance Information (FMPPI) and Statistics South Africa has introduced South Africa Statistics Quality Framework (SAQAF) (National Treasury, 2007:3; Presidency, 2007:1, 2011:1).

Lastly, in the year 2011, the National Evaluation Policy Framework was launched; and this completed the picture of the GWM\&E System in South Africa (Presidency, 2011:1).

\section{The Aim of Evaluation in South Africa}

It is clear that the aim of evaluation in South Africa is to address the problem of evaluation in government institutions, which used to be conducted sporadically, and which often did not adequately inform planning, policy-making and budgeting, and this denied the government-wide or all spheres of government an opportunity to improve their programmes and projects' relevance, effectiveness, efficiency, impact and sustainability on their priority outcomes (Presidency, 2011:1).

Subsequently, making decisions by only relying on performance information gathered through monitoring for the purpose of reporting is not substantial, because monitoring does not expose inherent problems that sometimes are the causes of lack of quality performance in all spheres of governments. In answer to this issue, Engela and Ajam (2010:26) indicate that evaluation provides the opportunity to go beyond merely reporting to understanding why phenomena happen, which can take the form of the attribution of linking inputs, processes, outputs, outcomes, and impacts within a broader conceptual perspective.

When above is taken into consideration, relevance; effectiveness; efficiency; value for money; impact; and sustainability are an actual key part of the main evaluation issues (Presidency, 2011:7).

Cloete and De Coning (2011:199) citing Davis, Newcomer and Soydan (2006:165) reveal that among other benefits, these evaluation issues could enhance the efficiency, cost-effective performance, and also reduce waste in all spheres of government, which then prompted national government to introduce outcomes approach to service delivery in all three spheres of government. 


\section{An Outcomes Approach}

According to the late former Minister in Presidency, Collins Chabane (2010), he maintained that since 1994, the South African government in all spheres has achieved a great deal on providing services to the people. Unfortunately, a huge increase in expenditure could not produce the required results, which is the reason why outcomes and measurable outputs approach was introduced.

Among the twelve (12) key outcomes introduced, the Cabinet has identified outcome nine (9) as a local government performance outcome, and relates to a responsive, accountable, effective and efficient local government system. According to Chabane (2010), key outputs for local government would be to meet the basic needs of communities, building a clean, responsive and accountable administration.

In view of the above, clear statements of outcomes for achievement and clear indicators, baselines, as well as targets to measure change should ensure that local government get reliable information, which can be used to monitor progress, evaluate government successes and plan to improve performance (Guide to the Outcomes Approach, 2010:10). To this effect, in order to ensure the evaluation of outcomes successfully, outcomes statements should be specific with regard to the target, and the required level of change or difference to be achieved, as well as the time schedule for achieving such a difference (Cloete \& De Coning, 2011:204).

Subsequently, it becomes clear that national government is taking measures to improve performance, and also committing itself to assist and support municipalities in their endeavours to deliver services efficiently and effectively to the people. In this way, the subsequent intergovernmental agreements on the ideal scope of services would also increase expenditure prioritisation, which leads to the issue of linking evaluation with budgeting.

\section{linking Evaluation with Budgeting}

As a point of departure, it should be noted that there are two characteristics that are needed for linking evaluation with budgeting. Firstly, evaluation information should be able to meet budgeting needs. Secondly, the focus of the budget process should be more on expenditure prioritisation and performance. As explained earlier in this article, expenditure prioritisation refers to local government's allocation of resources to the 
programmes or projects that deliver the greatest benefits to the community (Robinson, 2014:8 \& 29).

Thus, it should be recognised that the information needs of budget decision makers in municipalities are different from those of spending departments. While the municipal departments would seek to increase expenditure, the budget decision makers would seek to control or at times to reduce expenditure. To this, Robinson (2014:29) indicates that the action to cut expenditure on the existing programmes or projects, are measures of creating additional fiscal space for required new spending or rather to lower the overall expenditure of government; therefore, cutting and reducing of expenditure should be introduced by the Ministry of Finance.

Due to the principle of decentralisation in South Africa, there are three spheres of government, in this way, the cut or reduce of overall expenditure should be done by budget and treasury office in local government, or Treasury in provincial and national governments.

To demonstrate Robinson's (2014:29) argument, the then Minister of Finance, Pravin Gordhan, in his 2013 Budget Speech, having considered the Medium Term Budget Policy Statement, maintained we noted that if economic environment were to deteriorate, government would reassess its revenue and spending plans to secure South Africa's fiscal footing. To this end, the former Minister, also declared that over the next three years, new policy initiatives will be financed from savings, efficiency gains and reprioritisation of expenditure (National Treasury, 2013:9-10).

Additionally, Pravin Gordhan emphasised that previously, the Treasury used to significantly add to the medium term spending plans of national government during the budget in order to improve performance, but things have changed since then. He revealed that money has been taken away from programmes that were not performing or not aligned to the core priorities of the national government and given to those programmes that were delivering as expected (National Treasury, 2013:23).

The above National Treasury's position is essential, and should also be applied to municipalities, since they also receive revenue from the national government through 'Equitable shares system' (Engela \& Ajam, 2010:1). According to the Division of Revenue Act (2013:54), national share comprises conditional allocations to provincial and local spheres of government; general fuel levy sharing with metropolitan municipalities; and debt service cost as well as the contingency reserve. 
Now, considering the above, evaluation has a crucial role when budgeting for equitable shares. To this effect, Robinson (2014:10\&11) indicates that there are questions that the decision makers in the budget and treasury office as well as the Treasury could like to be answered when deciding on funding levels for programmes or projects that the national, provincial, and municipal departments undertake for service delivery improvements in municipalities, and they are the following:

- Spending proposals: Which of the spending proposals presented by national, provincial, municipal departments are likely to generate the required outcomes, which would be of importance as well as justify their costs to the citizens?

- Existing programmes: Which existing programmes, projects or municipal activities should be closed because of their ineffectiveness or not sufficiently effective to justify their costs? Here, the idea should not be only to identify ineffective programme or project, but to establish whether such a programme or project could not be upgraded. There is no need to close an ineffective programme or project while they could be made effective at a reasonable cost, either by modifying design or implementation strategy.

- Closing of programmes: Which current programmes, projects or municipal activities should be terminated as a result of their low relevance? That is, which programmes, projects or municipal activities are pursuing outcomes that are not valued by communities to justify the expenditure? (Robinson, 2014:10 \&11).

With regard to efficiency, Robinson (2014:11) indicates that municipal budget decision makers would like to know, how much should it cost to efficiently deliver specific services? In other words, the decision makers should attempt to obtain quantitative estimates of the potential budget savings that could be met through efficiency improvements, that is, estimates of the difference between the actual incurred cost of service delivery and the efficient cost.

On the issue of impact evaluation, Cloete and De Coning (2011:199), posit that a well-executed evaluation should be able to reveal the nature and extent of impacts which are expected, and which should then assist decision makers to identify the programmes and projects that are likely to generate the best returns on the resources used. 
In addition, the process of evaluation should also enable the decision makers to determine the observed changes which are not the results of the programme or project, but do actually emanate from external factors. This could assist decision makers to avoid investing in programmes and projects that are unlikely to result in the required benefits (Cloete \& De Coning, 2011:199).

Given the above, it is clear that evaluation becomes an extremely important instrument when expenditure decisions are made, particularly in providing performance information needed for budgeting, which requires that types of evaluation be investigated into.

\section{Types of Evaluation}

Literature identifies generally recognised types of evaluation, which are classified into three categories, namely, ex-ante evaluation; on-going evaluation; and ex-post evaluation (Cloete \& De Coning, 2011:199-200; Cloete \& Wissink, 2000:215-216; ljeoma, 2010:347; Robinson, 2014:12). For the sake of brevity, these types of evaluation are briefly discussed.

- Ex-ante evaluation: sometimes referred to as prospective, appraisal or a feasibility study, is conducted before a specific programme or project could be implemented. The analysis is conducted during development of the programme or project to achieve the required improvements.

- On-going evaluation: also known as process evaluation. Is normally used to analyse programmes' or projects' implementations so as to improve performance (efficiency and effectiveness). The main aim of this evaluation is to identify policy, programme or project design or needed management changes in order to ensure effectiveness.

- Ex-post evaluation: also referred to as outcome or summative evaluation. It aims to discover the extent to which the programme or project's required changes are accomplished. In other words, it refers to the extent to which the programme or project has managed to meet the desired outcomes. Ex-post evaluation also includes cost-benefit analysis and cost-effectiveness analysis (Cloete \& De Coning, 2011:199-200; Cloete \& Wissink, 2000:215-216; Robinson, 2014:12). 
It is generally recognised that each of these types of evaluation are crucial and relevant to effective budgeting (Robinson, 2014:12). When all above information is taken into consideration, certain findings or conclusions could be ensconced.

\section{Findings from the literature}

Seeing a literature review was used as a method to reach conclusions in this study, it was firstly, indicated that the global economic crisis is continuously affecting government fiscals negatively. Secondly, it shows that the Constitution, 1996 and the consequential policy frameworks prescribe the fundamental rights or socio-economic rights of the people in South Africa. It is clear that global economic crisis restricts municipalities and other role players in their service delivery. A further negative aspect is the continuous fruitless and wasteful expenditures incurred in municipalities.

Thirdly, it is also revealed that during planning and budgeting, decision makers should use criteria that reflect the hierarchical priority levels, in which allocation of limited resources should be prioritised. To this end, the following priority indicators are revealed:

- absolute priority;

- essential expansions or new programmes;

- desirable expansions or new programmes;

- useful expansions or new programmes; and

- expendable extensions or new programmes.

Fourthly, it was found that M\&E in South Africa is a matter of policy requirements. To this end, evaluation should provide the opportunity for local government to improve the programmes and projects' relevance, effectiveness, efficiency, impact and sustainability. Fifthly, national government has introduced the outcomes based approach, which amongst the 12 outcomes, only outcome nine (9), that is, a responsive, accountable, effective and efficient local government system, is directly related to local government.

Lastly, on linking evaluation with budgeting, the literature posits that there are two distinguishing features that should be met. Firstly, evaluation needs should be aligned to the purpose of budgeting. Secondly, the budget process should be more geared towards expenditure prioritisation and performance. In order to achieve these requirements, interpretation of effectiveness, efficiency, and impact of programmes and projects is essential. The most effective way of interpreting the foregoing can only be reached by 
using types of evaluation. Specifically, for existing programmes and projects, on-going evaluation and ex-post evaluation are critical approaches that could be useful to link evaluation with budgeting for the achievement of service delivery in municipalities. All these findings require that recommendations be put forward to be able to address the discovered challenges.

\section{Policy recommendations}

It is recommended that evaluation should be linked with budgeting in order to promote good performance in municipalities. Although, evaluation is instrumental in making decisions for other aspects in local government, which among other things, include planning, but for the budget decision makers, it should be a valuable tool that is crucial to promote efficiency and effectiveness of financial management in municipalities. In this way, this suggests that performance information gleaned through ex-post or outcome evaluation should be the premise when determining the level of funding to the proposed municipal budgets.

This then, requires that the questions designed for outcome evaluation of programmes and projects should be able to adequately elicit the needed performance information, which should be useful to the budget decision makers when they consider expenditure prioritisation. To this end, examples of outcome evaluation questions that could be considered for use to determine relevance, efficiency, effectiveness, and impact of municipal programmes, projects or other activities are provided as follows:

Relevance: which programmes, projects or activities that should be considered for termination due to the lack of relevance or being not so important to the community to justify their costs? Which programmes, projects or activities are likely to produce the required outcomes to justify their costs?

Efficiency: how economically can specific services be delivered and obtained without compromising quality?

Effectiveness: which existing programmes or projects should be terminated because of lack of cost-effectiveness? If not terminated, what could be done to make the programmes or projects sufficiently effective to justify their costs? How do various programmes' or projects' implementation alternatives compare in cost-effectiveness? 
Impact: which long-term effects will a programme or project have to the beneficiaries to justify its cost? What is the cost-benefit balance for a given programme or project? Which environmental/external factors may possibly thwart the long-term effect of the programme or project, and thus, cause waste?

It is recommended that the above should also serve as the key criteria for targeting the budget cuts. The relevance of existing programmes and projects should continuously be assessed in order to inform budgeting for municipal activities. As Robinson (2014:33) indicates, the relevance is as important as the efficiency and effectiveness of the programmes or projects.

When finding a programme or project ineffective, it is recommended that decision makers should always seek to establish whether there are possibilities of improving or fixing the deficiencies that might have led to the programme's or project's ineffectiveness. It does not serve any purpose to cut funding to a programme or project which requires a better planning or improved management. Hence, Robinson (2014:30) suggests that it is critical, firstly, to conduct additional analysis to assess whether the programme or project is 'fixable'.

It is also crucial when impact evaluation is conducted, that external or environmental factors that could have an impact, either positively or negatively upon the outcomes of the programmes or projects are assessed, analysed, and understood. This would assist future attempts to identify the role of the programme or project, as well as other factors, which could contribute, either positively towards the development of the lives of people in communities, or rather, negatively which could result in wasting the public money, the latter acting as a cue to avoid investing in programmes or projects that waste resources in the future.

In order to achieve stipulated outcomes successfully, outcome statements should be specific in relation to the target, and the required differences to be achieved, as well as the time schedule for achieving such changes.

Lastly, it is also important that evaluation should inform budget decision makers about the required capacity levels in municipalities. This, is important for national and provincial governments, since section 154 of the Constitution (1996) stipulates that national and provincial governments, by legislative and other measures, must support 
and strengthen the capacity of municipalities to manage their own affairs, to exercise their powers and to perform their functions.

Therefore, information gathered through on-going or process evaluation should be more useful to inform budget decision makers in the provincial and national governments about the required capacity interventions, which could assist to deal with financial weaknesses in municipalities. Some of the weaknesses, such as using resources for unplanned, unbudgeted activities (at times provincial activities), items like t-shirts and bags, over-spending and under-spending tendencies, insufficient skills capacity in planning and project management, lack of controls, as well as lack of financial management, are always giving impetus to unauthorised, irregular, fruitless and wasteful spending. These issues should be effectively addressed through interventions from provincial or national governments.

\section{Conclusion}

The article started by analysing the two reports, that is, the reports of Auditor-General 2012/13 and Statistics South Africa's Non-Financial Census of Municipalities, 2013. It became clear that these reports show the paradox that is existing in terms of performance in South African municipalities. To that effect, this then presented a compelling case through which maximisation of expenditure prioritisation in municipalities had to be investigated.

At the point of departure, the article argued that Monitoring and Evaluation (M\&E) policy framework should be fully implemented. This was also in consideration of fiscal challenges which faced South Africa. The basis of this argument was that, the limited resources should be allocated to the most pressing problems which South Africans are subjected to. To this end, legal and policy mandates of local government were analysed, including priority indicators, legal basis of M\&E in South Africa, the aim of evaluation, the Outcomes approach, linking evaluation with budgeting, and types of evaluation. Having considered all mentioned issues, the literature review findings were presented, which eventually led to the recommendations raised in this article. 


\section{List of References}

- Chabane, C. 2010. An outcomes based approach to government [Internet]. Available from: http://www.politicsweb.co.za/politicsweb/vew/politicsweb/en/page71656?oid=160481\&sn= Detail [Assessed 4 June 2014].

- Cloete, F., \& De Coning, C (eds). 2011. Improving Public Policy: Theory, practice and results. $3^{\text {rd }}$ ed. Pretoria: Van Schaik.

- Cloete, F., \& Wissink, H. 2000. Improving Public Policy. Pretoria: Van Schaik.

- Cloete, J.J.N. 1995. Public Administration Glossary. Pretoria: Van Schaik.

- Development Bank of South Africa (DBSA). 2009. Water Supply and Sanitation in South Africa: Environmental Rights and Municipal Rights and Municipal Accountability. Pretoria: LHR Publication Series (1/2009).

- DNA Economics. 2012. Evaluation of the KZN Department of Economic, Development and Tourism Projects and Programmes Evaluation Framework [Internet]. Available from: www.kznded.gov.za/.../KZN\%20DEDT\%20Evaluation\%20Framework\%20Final\%2007082012.p df [Accessed 25 August 2014].

- Engela, R. \& Ajam, T. 2010. Evaluation Capacity Development: Implementing a Government-Wide Monitoring and Evaluation System in South Africa. Washington, DC: The World Bank. (ECD Working Paper Series No. 21).

- Erasmus, P.W. \& Visser, C.B. 1997. Government Finance: The First Step. Cape Town: Juta \& CO, LTD.

- Ijeoma, E.O.C. 2010. Mainstreaming Government-Wide Monitoring and Evaluation policy in South Africa: An eye on impact assessment. Journal of Public Administration, 45(2): 343360, June.

- Lomahoza, K., Brockerhoff, S., \& Frye, I. 2013. A Review of National and Provincial Government Budgets in South Africa: 2007/08-2011/12. Studies in Poverty and Inequality Institute. Johannesburg: SPII. (Working Paper No. 7).

- Mbanjwa, X. 2014. Stats SA gives municipalities mixed service-delivery scorecard. City Press [Internet]. Available from: http://www.citypress.co.za/politics/stats-sa-givesmunicipalities-mixed-service-delivery-scorecard/ [Accessed 3 September 2014]. 
- Robinson, M. 2014. Evaluation capacity development: Connecting Evaluation and Budgeting. Washington, DC: The World Bank group. (ECD Working Paper Series No. 30).

- Schwella, E., Burger, J., Fox, W., \& Müller, J.J. 1996. Public Resource Management. Cape Town: Juta \& Co, Ltd.

- Seemela, V.P. 2009. Local Government Finance III. Study guide 2 for LGF 381T. Pretoria: UNISA.

- Setumo, S. 2014. Less than $10 \%$ of municipalities receive clean audits. Business Day Live [Internet]. Available from: http://www.bdlive.co.za/national/2014/07/30/less-than-10-ofmunicipalities-recieve-clean-audits [Accessed 1 August 2014].

- South Africa. 2010. Guide to the outcomes approach, version 27. Pretoria: Government Printers.

- South Africa. 1996. Constitution of the Republic of South Africa. Pretoria: Government Printers.

- South Africa. Department of National Treasury. 2007. Framework for Managing Programme Performance Information. Pretoria: Government Printers.

- South Africa. Division of Revenue Act (Act No. 2 of 2013). Government Gazette No.36555. Pretoria: Government Printers.

- South Africa. Local Government: Municipal Systems Act (Act No. 32 of 2000). Pretoria: Government Printers.

- South Africa. National Treasury. 2000. Guide for Accounting Officers: Public Finance Management Act. Pretoria: Government Printers.

- South Africa. National Treasury. 2011. Example of SCHEDULE A: An Annual Budget and Supporting Documentation of a Municipality. Pretoria: Government Publishers.

- South Africa. National Treasury. 2013. 2013 Budget Speech [online]. Available from: http://www.treasury.gov.za/documents/national\%20budget/2013/speech.pdf [Accessed 8 October 2014].

- South Africa. Presidency. 2011. National Evaluation Policy Framework. Pretoria: Government Printers.

- South Africa. Presidency. 2014. State of the Nation Address by His Excellency Jacob G Zuma, President of the Republic of South Africa on the occasion of the Joint Sitting of 
Parliament [Internet]. Available from: http://www.gov.za/speeches/view.php?sid=43620 [Accessed 18 February 2014].

- South Africa. Statistics South Africa. 2014. Non-Financial Census of Municipalities, 2013 [Internet] available from: http://beta2statssa.gov.za/?p=3164 [Accessed 2 September 2014].

- South Africa. The Presidency. 2007. Policy Framework for the Government-wide Monitoring and Evaluation System. Pretoria: Government Printers.

- South Africa. The White Paper on Local Government. 1998. Pretoria: Government Printers.

- Van der Waldt, G., \& Du Toit, D.F.P. 1997. Managing for Excellence in the Public Sector. Cape Town: Juta \& Co, Ltd.

AUTHOR'S CONTACT:

MOFOLO, MALEFETSANE A.

Dept. of Management \& Governance

Walter Sisulu University

Email: mmofolo@wsu.ac.za 